\title{
University Technology Transfer Network Structure Development: Education and Research Quality Issues
}

\author{
Artem Artyukhov ${ }^{1}$, Vitaliy Omelyanenko ${ }^{1,2,3}$, Olha Prokopenko ${ }^{4}$ \\ ${ }^{1}$ Sumy State University, 2 R.-Korsakova st., Sumy, Ukraine \\ ${ }^{2}$ Institute of Industrial Economics, National Academy of Sciences of Ukraine, 2 Zhelyabova st, Kyiv, Ukraine \\ ${ }^{3}$ Sumy State Makarenko Pedagogical University, 87 Romenska st., Sumy, Ukraine \\ ${ }^{4}$ Collegium Mazovia Innovative University, 161 Sokolowska st., Siedlce, Poland
}

\begin{abstract}
The article analyzes the main models of technology transfer in Europe, the USA, Japan and China. The national legislative base in the technology transfer sphere is analyzed. The main reasons for successful (at a systematic level) mechanisms of the technologies transfer are determined. Leading tendencies of technology transfer development in leading countries are presented. The necessity of creating technology transfer centers at universities as a place of the state intellectual potential concentration is substantiated. Authors propose ways for increasing technology transfer efficiency based on the complex approach to promote scientific research results.
\end{abstract}

Keywords - Scientific investigations, Technology transfer, Innovations, University.

\section{Introduction}

The importance of technology transfer from science to business is above any exception. It is a mutually beneficial process in which both sides follow their aims.

DOI: $10.18421 /$ TEM102-16

https://doi.org/10.18421/TEM102-16

Corresponding author: Olha Prokopenko,

Collegium Mazovia Innovative University, Poland.

Email: prokopenko.olha.w@gmail.com

Received: 07 January 2021.

Revised: 01 April 2021.

Accepted: 07 April 2021.

Published: 27 May 2021.

(c) BY-NC-ND (c) 2021 Artem Artyukhov, Vitaliy Omelyanenko \& Olha Prokopenko; published by UIKTEN. This work is licensed under the Creative Commons Attribution-NonCommercial-NoDerivs 4.0 License.

The article is published with Open Access at www.temjournal.com
For the scientist, it is prestige in the scientific community and additional income from creative and intellectual activity results. For business, it is production efficiency increase (e.g., economic and ecological), outcome to a new level of technique, extending of clients net, and producing internationalization.

At the same time, technology transfer issues are problematic for countries that are developing national innovation systems. This problem deepens as the mechanisms of innovative cooperation become more complex and technologies become more complex. In these conditions, the role of universities and research centers, which accumulate innovative potential, requires its own conceptual rethinking in terms of participation in these processes [1].

\section{Literature Review}

Technology is a "good" at the market [2]; scientists' intellectual potential may also be estimated in money terms. Problem decision of establishing links between science and business both within a particular country and at the international level is an urgent task for both participants [3].

The organization model of university intellectual potential commercialization and its technology transfer provides a specialized functional subdivision, i.e. technology transfer center [4]. The task of the technology transfer center is to assist with project development from an idea to successful enterprise. Any university is interested in getting maximal surplus value from technology commercialization. The higher development (improvement) stage of the product, the more expensive it may be sold.

University can be a generator of new ideas, implement them in real investigations and technologies transfer centers can conduct the function of "mediator" between science and business, improving education and research quality. At the 
same time, transfer success depends not only on them [5]. State support has to be in the foreground while creating an effective transfer mechanism. How is it expressed? There are several examples:

- Consider innovative development as a priority state orientation;

- Increasing of public financing of science;

- Improvement of mechanisms to distinguish public financing between universities;

- Improvement of normative base in the sphere of technology transfer;

- Support universities owing to public orders in priority directions of science and technique development.

Systematic problems in technology transfer may be found not only at the state level. The main problems include:

- Scientists and their communications with the business;

- "Purity" of scientific investigations (ethics and academic integrity);

- Scientists and investors have different views: one - about unique technologies, the other - about profit and risks.

- Scientists' of post-Soviet mental structure, the complexity of science and business communications, incomprehension of transfer peculiarities, attraction to publish and to accept personal work and as a result - the public reveal of information, which made patenting impossible;

- Low motivation of scientists and business to be engaged in high tech development;

- Scientists cannot promote their scientific investigations, and he or she does not ask for assistance owing to unwillingness to share profit from commercialization;

- Technologies are not brought to commercialization level, cannot pass a technological audit, there are no experimental samples, business-plans;

- Research, design and experimental works without market demand;

- Administration of most scientific establishments is not ready to work in conditions of competition with other scientific institutions;

- Weak science cooperation between universities;

- Necessity of additional financing to bring investigations to the commercial level;

- Absence of market analysis, a discrepancy of supply and demand.

Information about scientific investigations includes:

- insufficient quantity of innovative networks elements in technology transfer departments;
- irregularity of innovative infrastructure distinguish in regions, absence of large scientific unions, which may perform researching activity and commercial transfer in a controlled way and satisfy native enterprises needs in qualitative and innovative producing technologies;

- problem of university current investigation bank creation;

- information collected in databases has incorrect data;

- low activity of technology transfer networks;

- insufficient activity of technology transfer to promote investigations in European networks;

- absence of only one form to present scientific investigations for business.

Business involves:

- sharp contrast between leading high technology enterprises and enterprises with low labor capacity and weak strivings for innovations;

- absence of R\&D centers at enterprises;

- businessmen's ignorance of necessary, developed technologies;

- entrepreneurs' ignorance about the existence of technologies they need, even already developed;

- distrust to quality of investigated native technologies;

- absence of base to check experienced sample due to enterprises unwillingness to cooperate;

- most innovative projects warrant their realization only in case of coming to sizeable industrial production;

- risks while product development;

- corruption and influencing of bad investment climate;

- absence of venture funds.

The crisis in 2007-2009 in Ukraine vastly complicated introducing scientific investigations into the economy. Within strict saving of material resources, enterprises do not want to risk owing to new technologies introduction. Starting at the end of 2013 and continuing until now, the new crisis wave brought science and technologies transfer to our state's last problems.

Revolution of Dignity may become a "catalyzer", which hasten the development process in Ukraine as an innovative European state.

After the Revolution of Dignity, improvement in legislation in technology transfer has a "cosmetic" character. In p. 5 of Article 69 of the Higher Education Act of Ukraine, it is mentioned that "higher educational establishments perform events to introduce, including technology transfer, objects of intellectual property rights, ownership rights for which they received". There is no information about mechanisms to conduct technology transfer in the mentioned Act of Ukraine and the Scientific and 
Scientific technical Activity Act of Ukraine, State Control of Technology Transfer Activity Act.

Other problems mentioned above are also partially solved: innovative and informational networks are formed, multidisciplinary scientific research becomes more popular, but not of mass scale. The most significant change is that the university (investigator) starts communication with a scientific production customer. Nowadays, scientific researches and investigations are performed on customer's demands. It increases the efficiency of technologies introduction into the producing process.

The purpose of the presented study is to consider the conceptual issues of creating models of technology transfer at universities, considering the best world practices focusing on regional development.

\section{Results}

\section{- Center of technology transfer}

The center of technology transfer is not merely the line between science and business. It has to perform other functions, which were not conducted earlier:

- Center of scientific grant activity development (search of potential customers owing to the joint research performance);

- Research center conduct "cleanness", academic integrity in science;

- Communicator with technology transfer networks at national and international levels.

Creating a technology transfer center, which allows observing the commercialization problem in a complex way, is a thriving university's primary task. University with a wide range of scientific directions is an excellent base for such center functioning. By the example of SSU, we will show how scientific investigations are turned into actual and attractive technical proposals. Unlike national networks of technology transfer, which is only the ideas and technological decisions repository, the center of technology transfer of SSU is the real promoter of scientific investigations.

At this stage, university and industry (despite opposite tasks, based on their activity) also can have common interconnection motives, such as:

\section{- University:}

- Knowledge and information concerning information about fundamental studies on new technologies development;

- Direct technical support;

- strengthen interconnections between technical personnel from various organizations;

- Decrease of costs and probability of risks;

- Access to objects of intellectual property rights;

- Information about competing organizations;
- Stimulating creative work to conduct new research projects and science-intensive investigations;

- Invitation of perspective and intelligent students for future workers.

\section{- Industry:}

- Extension of scientific research fund financing sources;

- Determination of innovative activity stimulation ways;

- Providing the ability for students to have a working place.

Dignity's Revolution throws Ukraine into a dilemma - to continue to fall or to turn into a robust, powerful state with a developed intellectual base. The second way is very complicated, and regional technology transfer centers' development is booming.

\section{- Technology transfer management's world experience}

This part of the material shows that it is interesting to analyze technology transfer management's world experience at universities. The main constituent in the technology transfer center at the university will be defined.

The compelling state control of technology transfer problems in developed countries was started in 8090s XX century.

Examples of legislative "breaks" in the world practice of technology transfer sphere include:

- Patent and Trademark Law Amendments Act or Bayh - Dole Act (the USA, 1980);

- Science and Technology Basic Law (Japan, 1995), "Special measures of the industrial liveliness" or Japan version of Bayh-Dole Act (Japan, 1999);

- Act about innovations and scientific research (France, 1999).

Ukrainian legislation cannot boast with acts "for scientists". The whole normative base allows only conducting technology transfer. There is no answer in the legislation base on how to do it.

Table 1 generalized list of actions used within the European research area and could be introduced in Ukraine is given.

Nowadays, competitiveness and advantages of knowledge investigation system are also determined by innovative process participants' adaptive ability to combine various skills and innovative technologies through cooperation («co-development» and «cospecialization»). In this case, the Quintuple Helix model includes platforms with open architecture, where various knowledge types can be combined [6].

Technologies are essential objects of intellectual property (OIP) rights. Technology constituents may 
be several inventions, applicable models, industrial objects, product marks, author's rights objects, commercial secrets (know-how), which are objects of intellectual property [7], [8]. It is well-known that scientific investigation introduction in today's economic realities is not a simple question and often needs much effort and time than its creation.

In Ukraine, the problem of technology transfer has to be observed at various levels and, first of all, together with economic trends.
Unfavorable statistics demonstrate an insufficient level of communication in the economic system. For example, public-funded organizations conducting research and investigations are given numerous projects to be used in the industry.

In this context, the proper Act Project "Introduction of changes in some Ukrainian laws (concerning the regulation of some questions and stimulation of activity in technology transfer sphere)" has potential, but it has not systemic character.

Table 1. Comparative experience of the EU countries and Ukraine innovative development

\begin{tabular}{|c|c|c|c|}
\hline Criterion & $\begin{array}{c}\text { TOP-10 innovative countries } \\
\text { of EU by GII }\end{array}$ & Ukraine & $\begin{array}{c}\text { Conclusion for the innovative policy of } \\
\text { Ukraine }\end{array}$ \\
\hline $\begin{array}{l}\text { Structure of the } \\
\text { innovative national } \\
\text { system }\end{array}$ & $\begin{array}{l}\text { National and regional level } \\
\text { with proper functions. } \\
\text { Coordination of the innovative } \\
\text { and economic policy }\end{array}$ & $\begin{array}{l}\text { Formation of the } \\
\text { national level, } \\
\text { absence of the } \\
\text { innovative policy at } \\
\text { the regional level }\end{array}$ & $\begin{array}{l}\text { Development of regional competitive } \\
\text { advantages, based on innovative criteria, } \\
\text { financial providing of the regional } \\
\text { authority powers in the innovative } \\
\text { system }\end{array}$ \\
\hline $\begin{array}{l}\text { Model of innovative } \\
\text { process }\end{array}$ & $\begin{array}{l}\text { Model of the open innovations, } \\
\text { effective technological market }\end{array}$ & $\begin{array}{l}\text { Close model of the } \\
\text { innovative process }\end{array}$ & $\begin{array}{l}\text { Transfer to open innovations model, } \\
\text { based on economic system demand }\end{array}$ \\
\hline $\begin{array}{l}\text { Target orientation of } \\
\text { innovative } \\
\text { development }\end{array}$ & $\begin{array}{l}\text { State priorities based on the } \\
\text { maximal competitiveness of } \\
\text { technologies }\end{array}$ & $\begin{array}{l}\text { Numerous state } \\
\text { priorities without } \\
\text { proper structure }\end{array}$ & $\begin{array}{l}\text { Concentration on limited priorities } \\
\text { number with proper resource providing } \\
\text { and development potential }\end{array}$ \\
\hline $\begin{array}{l}\text { Instruments of } \\
\text { development by } \\
\text { priorities }\end{array}$ & $\begin{array}{l}\text { Programs of innovative policy } \\
\text { by the functional orientation }\end{array}$ & $\begin{array}{l}\text { Target programs of } \\
\text { given sectors }\end{array}$ & $\begin{array}{l}\text { Programs of the innovative policy by the } \\
\text { sectors priorities or by innovative } \\
\text { orientations (e.g., space strategy) }\end{array}$ \\
\hline $\begin{array}{l}\text { State innovative } \\
\text { structures }\end{array}$ & $\begin{array}{l}\text { The practice of innovative } \\
\text { agencies }\end{array}$ & $\begin{array}{l}\text { Innovative structure } \\
\text { atomism }\end{array}$ & $\begin{array}{l}\text { Systemic modernization and } \\
\text { coordination of the innovative system } \\
\text { components functioning }\end{array}$ \\
\hline $\begin{array}{l}\text { Compensation of } \\
\text { costs for patenting }\end{array}$ & According to priorities & $\begin{array}{l}\text { Absent in systemic } \\
\text { form }\end{array}$ & $\begin{array}{l}\text { Introduction of compensating } \\
\text { mechanisms by chosen priorities }\end{array}$ \\
\hline Technology transfer & $\begin{array}{l}\text { Developed cooperation } \\
\text { between science and business } \\
\text { (AplusB) }\end{array}$ & $\begin{array}{l}\text { The gap between } \\
\text { science and business }\end{array}$ & $\begin{array}{l}\text { Introduction of the science target } \\
\text { character } \\
\text { Commercialization and marketing of the } \\
\text { university science }\end{array}$ \\
\hline $\begin{array}{l}\text { The strategy of } \\
\text { innovations } \\
\text { internationalization }\end{array}$ & $\begin{array}{l}\text { International clusters and } \\
\text { networks development }\end{array}$ & $\begin{array}{l}\text { International } \\
\text { projects Initiative } \\
\text { cooperation }\end{array}$ & $\begin{array}{l}\text { Introduction of strategy on active } \\
\text { clusters internationalization and creation } \\
\text { of new ones }\end{array}$ \\
\hline $\begin{array}{l}\text { Cluster strategy of } \\
\text { innovative } \\
\text { development }\end{array}$ & $\begin{array}{l}\text { Clusters as the method of high } \\
\text { technological export supply }\end{array}$ & $\begin{array}{l}\text { Clusters at the local } \\
\text { and national levels }\end{array}$ & $\begin{array}{l}\text { State supply of development based on } \\
\text { international cooperation. } \\
\text { Innovative development of Euro- } \\
\text { regions. } \\
\text { International marketing of acting } \\
\text { clusters }\end{array}$ \\
\hline $\begin{array}{l}\text { Financial supply of } \\
\text { innovations }\end{array}$ & $\begin{array}{l}\text { State-private partnership with } \\
\text { significant state role }\end{array}$ & $\begin{array}{l}\text { State financing of } \\
\text { researches in state- } \\
\text { owned legal entity } \\
\text { institutions }\end{array}$ & $\begin{array}{l}\text { Transfer to the practice of venture } \\
\text { business support and state guarantees, } \\
\text { privileges in the whole innovative } \\
\text { process cycle }\end{array}$ \\
\hline $\begin{array}{l}\text { Innovations } \\
\text { providing }\end{array}$ & $\begin{array}{l}\text { Stimulation of the target } \\
\text { investment }\end{array}$ & $\begin{array}{l}\text { Stimulation of } \\
\text { foreign investing } \\
\text { without target } \\
\text { direction }\end{array}$ & $\begin{array}{l}\text { Introduction of the motivate mechanisms } \\
\text { by chosen priorities, improvement of } \\
\text { legislation on foreign investment }\end{array}$ \\
\hline Legal regulation & $\begin{array}{l}\text { "Evolutionary" legal system } \\
\text { with innovations }\end{array}$ & $\begin{array}{l}\text { The gap between } \\
\text { practice and } \\
\text { normative supply }\end{array}$ & $\begin{array}{l}\text { Creation of an "innovative" legislation } \\
\text { system. Innovative Codex admitting }\end{array}$ \\
\hline $\begin{array}{l}\text { The strategy of the } \\
\text { personnel providing }\end{array}$ & $\begin{array}{l}\text { The strategy of personnel } \\
\text { providing in priority sectors, } \\
\text { competence centers at higher } \\
\text { technical school. The policy of } \\
\text { the personnel involving }\end{array}$ & $\begin{array}{l}\text { Absence of systemic } \\
\text { approach for } \\
\text { planning }\end{array}$ & $\begin{array}{l}\text { Introduction of stimulating criteria and } \\
\text { efficiency while paying for work, the } \\
\text { realization of academic process } \\
\text { coordination principle and branch } \\
\text { innovative development }\end{array}$ \\
\hline
\end{tabular}


Therefore we suppose that such local changes are inefficient without the Innovative and Investment Codex and the new organization and economic approaches to control innovative national systems, particularly while financing distribution and project efficiency estimation. In general, in 2015, expenses for various research and investigations, scientific brainpower training and scientific tracking decreased to 4,8 billion UAH or $8 \%$.

The danger for the innovative policy is that the oligarchic system is not interested in new technologies transfer - techno-economic basis, which forms living society level and place of the state in the world. Integrating business-structures bank on the "fast" money of raw economy, which with low prices for energy products and the absence of strategic expenses (investments into innovative development), was over competitive at the world markets. For example, native metallurgy in technical and technological factors lags from foreign manufacturers because a significant part of the Ukrainian steel is melt in open-hearth furnaces. Metallurgical plants have already come to the innovative electric melting and oxygen convector production in the whole world. The innovative system degradation occurs in the background due to the demand absence of scientific research and 'brain drain" in the country with better self-realization conditions.

\section{Table 2. Organizing forms of the OIP transfer}

At the university level, the critical problem is choosing the most effective forms of the financing resources supply, which provides the ability to consider scientific study results and correlate results with costs to evaluate the efficiency of conducted fundamental science expenses. In the context of the national innovation system in Ukraine, proportions between public and private financing sources are also of special attention. It includes the ability and aptitude to involve private resources while financing separate fundamental projects and state support in university research.

Before analyzing some aspects to realize technology transfer by universities, it is necessary to give some explanations. Researches [9] allowed classifying the famous list of the commercialization (transfer) organizing possible variants OIP by two directions (Table 2). The first one is connected with the intellectual (staff) and the university's technical and technological resources. Therefore scientific and technical achievements cannot be separated from their carrier, i.e., personnel or technological resource which created those achievements. The second direction of the scientific and technical achievements commercialization organizing forms is based on the rights for OIP. It is connected with the ability of scientific and technological achievements carrier to be separated from the achievements. Property rights for created OIP by proper persons and communities may be possessed by another organization and be a profit source and meaning of participation in the scientific and technical achievements process.

\begin{tabular}{|c|c|}
\hline \begin{tabular}{ll}
\multicolumn{1}{c}{ OIP, not separated from its carrier } \\
- & technical service; \\
- & analytical service; \\
- & constructive service; \\
- & engineering; \\
- & orders for research, experimental and constructive \\
& works; \\
- & consultation service; \\
- & educational service; \\
- & outsourcing; \\
- & only personal use of OIP
\end{tabular} & $\begin{array}{ll} & \text { OIP, separated from its carrier } \\
- & \text { licensing of rights for OIP; } \\
- & \text { the transition of know-how; } \\
- & \text { the full purchase of rights for OIP; } \\
- & \text { franchising; } \\
- & \text { joint enterprises; } \\
- & \text { production and sell of goods; } \\
- & \text { creation of "spin-out" firms to transfer } \\
- & \text { OIP; } \\
- & \text { use as a pawn; } \\
- & \text { invest in further capital }\end{array}$ \\
\hline
\end{tabular}

Two types of transfer are the most popular for universities: order fulfillment for scientific and research and experimental-constructive works and licensing rights for OIP.

Profit from the licensing activity of universities is not primary. Licensing sell has a non-systemic character because there is no strict sell algorithm set at the national level.

The backside of "on a by-order" research processes is knowledge sale for a symbolic price. The main product within similar agreements with customers one of the further stages in scientists' and personnel scientific works - may be far from the final product.
In the world practice of university transfer to innovative centers access to information about current investigations, positive reputation and scientists' trust has to be earned, which can be accomplished through work for several years.

Therefore in the contest of technology transfer control, implicit knowledge factors are not more often considered, including habits (skills) and culture that we have but not that we realize.

One of the famous scientific aphorisms by M. Polanyi, author of the implicit knowledge conception, - "We know more than we can tell". Due to Polanyi's conception, implicit knowledge is 
collecting personal, uncodified knowledge, implemented in the experimenting and scientists' theoretical skills art, which is transferred through informal ways and human contacts.

Today in Ukraine, there is no closed cycle between research institutions, technology transfer centers and the industrial sector. Besides, scientists are often engaged in "science for science". Researchers often conduct much science-intensive research in various sectors, many investigated technologies, but a few innovations. Innovation is derivative from research, product at the market, and purchased by the consumer.

After the Soviet Union collapse and Ukrainian independence, research was not the main priority of in-state development. New ideas generation and creation of innovative technologies are conducted mainly on the scientists' enthusiasm. Normative base regulating technologies transfer mechanisms is also imperfect and needs modernization. These problems lead to systemic fall and deepening "Death Valley" between science and business. In "Death Valley", those ideas "die", which do not correspond to requests and requests are impossible to fulfill without additional funds (made by domestic industry with great displeasure).

"Death Valley" will be increased as long as there will be no communication between science and business. This communication has to be provided by the mediator - technology transfer center (Figure 1).

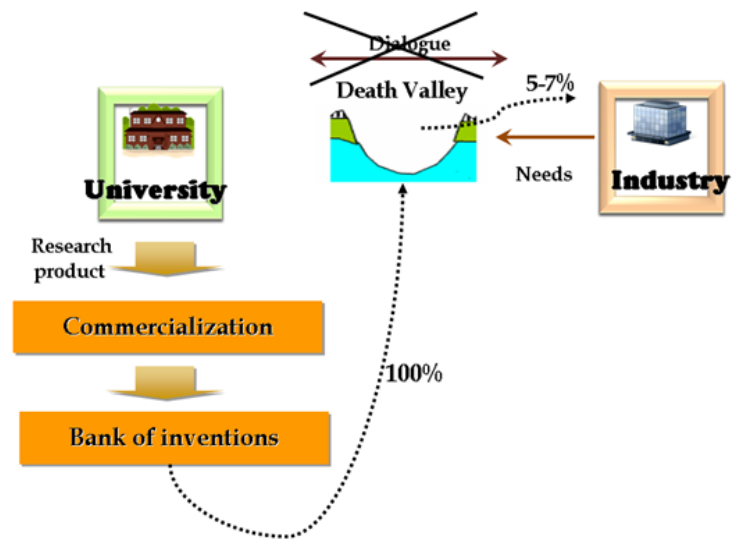

a)

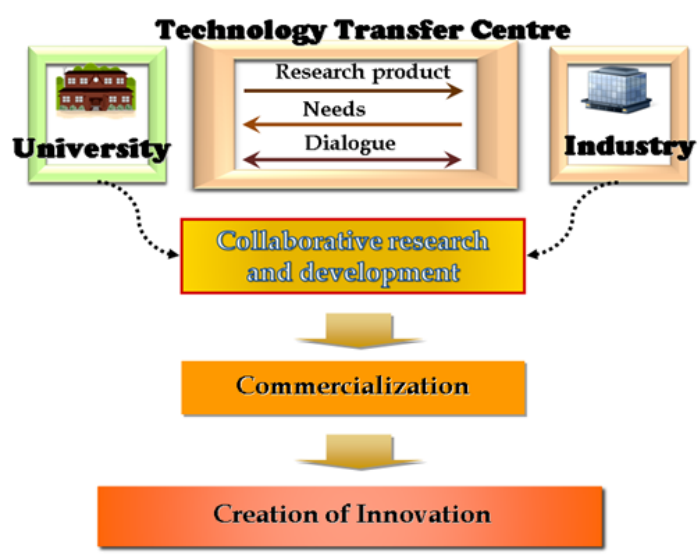

b)

Figure 1. Model of technology transfer: $a$ - existing model in Ukraine

$b$ - the model used in developed states
Practically at every university, there is a subdivision, which has to coordinate the technology transfer process. These are independent centers (centers of innovative development, technology transfer, intellectual property, scientific and technical and economic information), and departments comprised of the research department. The connection unit's function between science and industry in these centers can be performed only partially (e.g., informational base of scientific investigations, department of guiding work on OIP rights receiving).

Technology transfer in some countries (e.g., USA, Finland) is raised to the third university mission's status, non-fulfillment of which implies university punishment by way of rights deprivation for created intellectual property. A study of the scientific and research sphere in the USA revealed that $51 \%$ of state laboratories and $23 \%$ of universities examine technologies transfer as a primary mission, fundamental research $-70 \%$ of universities and $42 \%$ of state laboratories, technologies transfer into the industry $-40 \%$ and $52 \%$ [10].

Ukraine, according to The Global Innovation Index 2014 , is in 45 th place in the group of human capital level estimation factors and scientific research conduct (human capital \& research). Simultaneously, only 105 th place in the factors group characterizes innovative connections development between science and industry (innovation linkages).

In the context of overcoming this gap, we consider the most significant peculiarities to realize scientific and technological projects within the EU program:

1) International character of scientific and technical investigation with the obligatory condition to participate within one project of scientific groups from several states;

2) Priority orientation in most scientific applied studies and presenting real innovative investigation for commercialization as a project result.

Now we will mention some examples, which will be successful in Ukraine.

Coventry University Enterprises (CUE Ltd), subsidiary of higher education corporation Coventry University, through which university puts most of its commercial programs and business partnerships. Working at regional, national, European, and international levels, CUE supports corporative goals and tries to increase university, experience, and resources' maximum commercial potential.

Wales Innovation Relay Centre (WIRC) is a part of the European network IRC, created to stimulate international technology transfer and promote innovative service. Located and partially financed by Welsh Development Agency, the center is engaged in 
technological and innovative group formation problems and realizes close work with regional managers on business build/creation in the business support agency department's critical directions.

European network of advantages center in nanobiotechnologies sphere "Nano2Life" is created within the VI Framework program. The purpose of its creation is to reorganize into a virtual European nanotechnological institute. It unites researchers and scientific centers from 12 countries, including Canada, the USA, South Korea and Australia and about 30 associating partners - representatives from universities and industry. Over 40 consortiums concerning joint project development were organized. Participants of the network are biotechnologies companies (35\%), instrumentmaking (32\%), micro- and nanotechnologies (14\%, accordingly) and computer technique (5\%).

\section{- Technology transfer center model}

Among the main reasons for the technology transfer center establishing in university structure, we identify follows:

1. Most objects, which can be commercialization subjects in the future, are created within universities and scientific establishments where there is significant intellectual potential. Participation of universities in technology transfer determines the efficiency of economic technologies turn, their export and import;

2. Involving of introduced technologies into industry;

3. Demographical crisis. e.g., at Polish universities, profit from scientific activity in comparison with students (payment for study) and state financing is continuously increased. Effective technology transfer allows compensating losses of students and profit decrease from educational activity;

4. Efficiency of the technologies transfer depends on the efficiency of separate chains work "regional center - national center - international center". Coming out at the international level is practically impossible without regional technology transfer center.

The proposed project of development of a university technology transfer center is based on the principle of an integrated approach for implementation of mechanisms of technology transfer based on such components:

- coordinating university activities in the direction of intellectual property rights protection;

- creation of an interactive database of scientific investigations and possibility of information transfer with the business through the forms of technology requests and technology offers;

- cooperation with national and international technology transfer networks;

- marketing of innovations;

- coordinating university activities in the area of international scientific grant activities to attract foreign customers.

It is agreed with the modern innovation theories [11]. The innovation system is based on the interaction and knowledge exchange in the open innovation model. Additionally, high technologies should be implemented with many sources of different knowledge systems of innovation (enterprises, universities, research centers, consumers, and suppliers) from different countries. According to this, exactly networks most efficiently can acquire an international dimension [1].

World experience shows that with an increasing lag of the state in the technological sphere, the government's role in implementing innovation policy (setting priorities, infrastructure, establishing innovative links in the economy and at the international level) will also increase.

In the context of innovation systems globalization and its role in developing high technologies, which are collaborative, we have developed an algorithm of the strategy of innovative international integration development to implement national competitive advantages and strategic priorities.

The proposed approach is based on the understanding that:

1) for the implementation of new innovative projects, it is necessary larger scale which cannot be guaranteed without an effective international market and channels of cooperation;

2) implementation of new innovative forms requires a systematic approach based on communication and cooperation;

3) speed of implementation is irrelevant without adequate control: the massive efforts of $R \& D$ and innovation funding does not guarantee appropriate results if targeted activities do not complement them; ability to meet industrial demand; an approach aimed at addressing the gaps forming of the value-added chain; advanced reporting and monitoring tools used by state bodies, adopted according to chosen policy.

Therefore in innovative inner contour is necessary:

- to analyze the innovative demand - to show the development and implementation of any technology industry leaders are ready to invest (possibly together with the government);

- to inventory of available innovative supply and develop an information system to ensure the implementation of scientific and technological capacity;

- government, science and industry should agree 
on a policy of "technological corridor" - the boundaries that define the basic directions of the innovation process;

- to stimulate an innovative domestic vision of traditional industries (processing industry, agriculture, energy, mechanical engineering, chemical industry) in which technological solutions can ensure profitability in the short term.

An essential aspect of state regulation is to ensure socio-economic conditions of innovative development - the creation of social clusters in order to preserve the human capital of innovation:

- Organization of university graduates training that meet the modern requirements of the area and can adapt their changes in the future;

- Attracting talented scientific and technical personnel from abroad by the creation of attractive working conditions;

- Increase staff mobility by promoting their movements between states and employers;

- An assistance to international companies through local intellectual resources.

In an external circuit, it is necessary to ensure:

- Participation in joint projects of applied

- Research, development and implementation of technologies. In the case of sales prospects of innovative technologies in foreign markets often create joint enterprise;

- Exports of capital goods and engineering services, as well as the franchising of small and medium-sized enterprises;

- Participation in subcontracts and distribution costs (space exploration);

- Recruitment of foreign researchers and technicians (electronics sector);

- Investments in the modernization of technology in partner states (joint projects).

As a base for implementing the suggested technology transfer mechanisms (university technology transfer center), we proposed using CSTEI (source: http://cnti.sumdu.edu.ua/en).

The mission of CSTEI is to provide efficient management of the implementation of research capacity for regional development benefits.

The structure of CSTEI consists of:

- Department of organization of research results publication;

- Department of intellectual property protection management;

- Group of technology transfer organization;

- Group of scientific grant activity organizations;

- Group of IT-support.

Now we will describe the main mechanisms of promotion of scientific investigations in CSTEI.

\section{- Intellectual property rights}

Essential functions of CSTEI to protect of intellectual property rights in the university are:

- organization and methodical maintenance of intellectual property rights;

- ensuring the acquisition of property rights to the University of intellectual property rights (license agreements, licenses sales of intellectual property);

- consulting concerning intellectual property rights protection;

- providing information services for patent research and design inventive and innovative solutions;

- preparation and submission of applications of intellectual property for patenting of scientific and technical investigations;

- information and analytical support of activities connected with the creation, preservation, and protection of intellectual property;

- development of database and maintaining of the register of obtaining protection.

In addition to these functions, the Department of management's protection of intellectual property of CSTEI has another vital mission. Hundreds of university patents may simply not have any interest in commercialization. Therefore in the commercialization of university technologies, a pullapproach is used, which in contrast to a pushapproach, realizes an active university position regarding research. The desire not to push the market all in a row and give to the market what is necessary is the main task of CSTEI.

\section{- An interactive database of scientific} developments

SSU has developed a material base and scientific infrastructure, including about 60 research units, inter-sectoral and regional centers and 15 laboratories and structures providing scientific services.

SSU has strong scientific potential. It promotes the active development of diverse scientific fields, including information technologies, theoretical and experimental physics, nanotechnologies and biotechnologies, medicine, theoretical and applied mechanics, ecology, chemical technology and equipment, energy-saving, pumping and compressor equipment, metalworking, environmental economics, humanitarian and military science.

The university realizes this potential through the implementation of research and development activities and scientific services in order of central and local authorities, organizations and enterprises of Ukraine, Belarus, Georgia, Estonia, Czech Republic, 
Slovakia, China, Cuba, Spain, South Korea, Poland, Russian Federation, national and international research foundations. Annually about 600 research contracts and agreements are executed.

The increase in volumes of non-public funding is achieved by effective advertising of main scientific activities of university and technology offers via the interactive regional information resource of innovation.

This resource is a "bridge" between science and industry. It is focused on integration improvement between customers of scientific investigations and services and their developers. The resource is united on one information platform of information about innovative developments of SSU, service requests to perform activities in various sectors, an online forum for information exchange between scientists and business, innovation news and a plan of R\&D activities. SSU is always looking for cooperation partners.

In section "Order" open projects are posted for work with qualified personnel who are needed. All registered users have access to the opportunity to participate in a forum to discuss all open questions concerning research and development orders. Any questions or comments can always be expressed by using the feedback form.

For example, we give the information package in section "Chemical Industry" - "Granulation equipment".

For an example of granulators' development in our previous research [12], the integrated approach for product quality improvement was shown. It was also promising areas for development including licensing and start-up companies establishing.

The vibrating granulator (Figure 2) is used in the chemical industry. It is designed to disperse the melt of nitrogen (ammonium nitrate, urea) and compound fertilizers into uniform droplets in a granulation tower [12]. Further, these drops are cooled and crystallized into solid granules in free fall in upstream cooling air.

Compared with other types of granulators used in industry, vibration granulators provide:

- the improved agronomic value of fertilizers;

- high operational reliability;

- preparation of monodisperse granules;

- elimination of sticking in towers;

- reduction of dust;

- intensification of heat transfer in a tower.
Vortex granulator (Figure 3) is recommended for chemical, petrochemical, food processing, metallurgical, and pharmaceutical industries [12]. It can be used for the granulation of various substances from solutions and melts. Vortex granulator allows obtaining granular products without granulation towers.

The granulators' primary method is granulation from melts, solutions, and suspensions, based on the improvement of granules flow dynamics.

The main advantages of granulator are:

- increasing the monodisperse of granules that grow in the vortex layer;

- preparation of granules of given structure with carrying out its classification on the size of granules;

- preparation of porous structure granules while maintaining their strength (without internal crystal structure destroying);

- possibility to considerably reduce the dimensions (particularly the height) of working space;

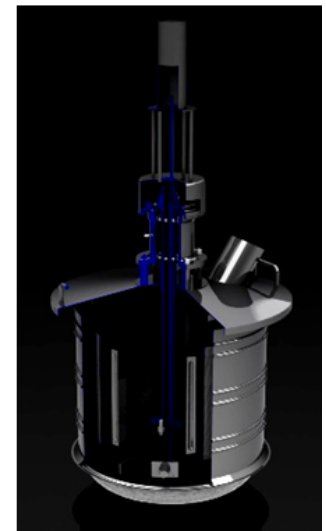

a)

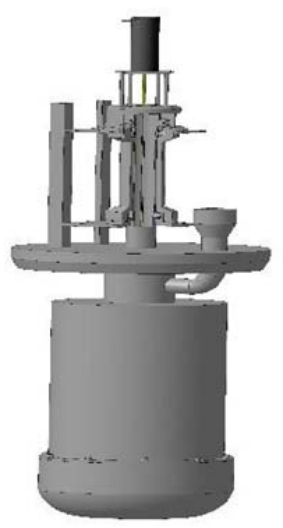

c)

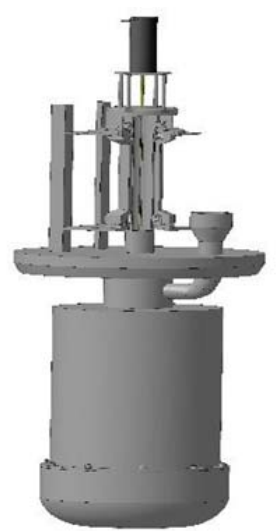

b)

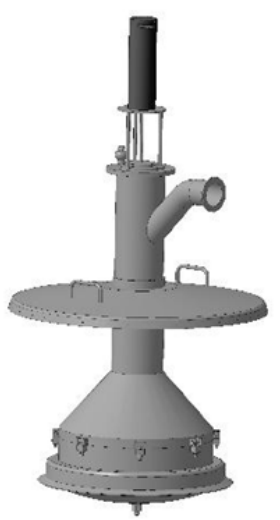

d)
Figure 2. Vibration granulators: $a$ - spinning; $b$ - rotality; $c$ - centrifugal cone; $d$-static 


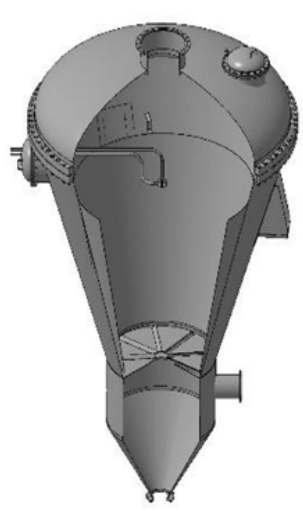

a)

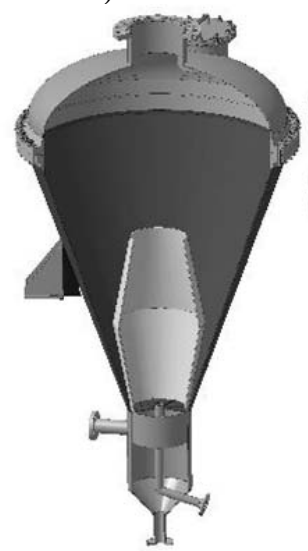

c)

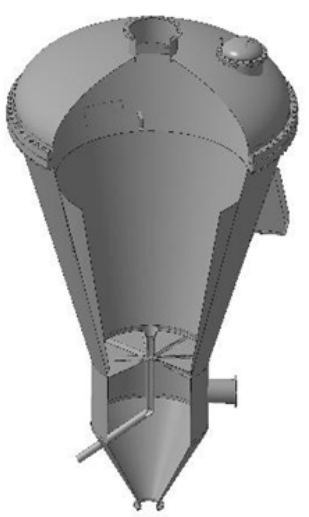

b)

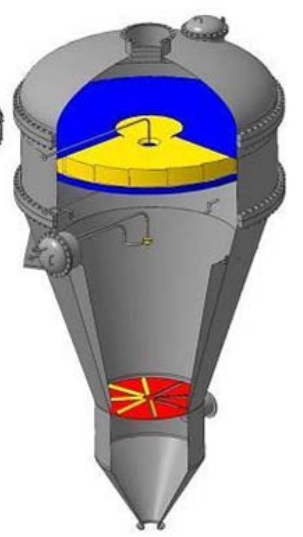

d)
Figure 3. Vortex granulator: $a$ - with melt spray; $b$ - with pre-moistened obtained granules and simple inner space;

$c$-with pre-moistened granules and composed inner space; $d$-with separation section

- increase in residence time of granules in the working space of device;

- the ability to control the granules motion in the workspace;

- ability to create a working space in the volume of intense turbulence;

- versatility (the possibility of granulation and drying processes in the amount of a single unit);

- ease of production;

- ability to quickly changing and readjustment of constructive and technological parameters.

Pan and blade granulators (Figure 4) are used in the food, pharmaceutical and chemical industries. They refer to a device used for balling and pelletizing the powders in the presence of a binder. Pelletizing powdered substance occurs due to compression of starting powder material due to the particles' mechanical action due to their collision with the board of a plate and upper layers pressure to lower granulate (pen granulator) due to exposure to moist particulate material and rapidly rotating blades.

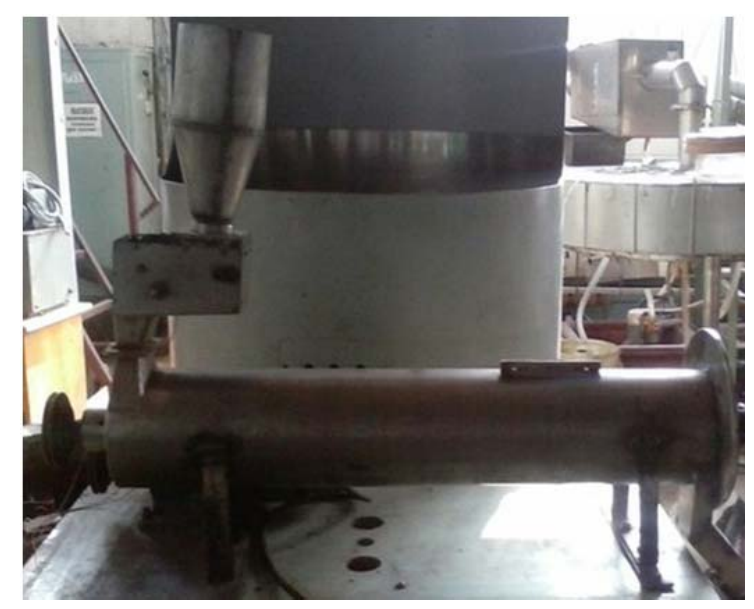

a)

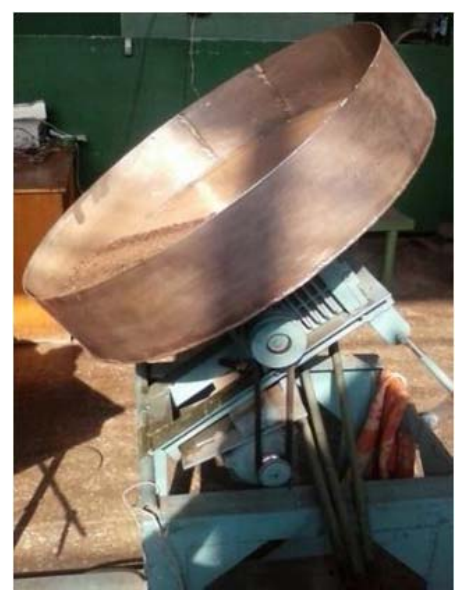

b)

Figure 4. Pan (a) and blade (b) granulators

Main advantages of proposed equipment are:

- Substantial uniformity of grain size at the device's outlet and reducing flow segregation due to retour granule size. At the same time, granules obtained greater strength and closed to spherical;

- Ease of granulation process control that allows quickly eliminates the possibility of deviation from the specified mode;

- Low cost of equipment, simplicity and reliability;

- Possibility of granulating hard and readily soluble fertilizer with a small amount of liquid phase, as well as complete granulation dosed mixture;

- Combination of processes of granulation and separation of particles.

\section{- Marketing of innovations}

Management of technologies and their transfer is more complicated than the management of innovations, which is caused by such factors [13]; [14]:

- Specificity of technology as the basis of the innovation process;

- Secondary character of technology regarding the final product, which is produced according to the technology, there is a need to carry out two 
studies of marketing: marketing of product potential and technology marketing;

- Duration of license contracts for technology sale that complicates the prediction of long-term consequences of technology transfer;

- In the case of technology, sales monitoring of competition (competitors technology is a closed trade secret) is too complicated;

- Weak regulatory pricing framework for licensing contracts, the unique nature of each technology, especially from high technologies, does not allow the use of a price-based approach unique. In this case, the license contract price is established due to prolonged economic calculations and negotiations between parties of the agreement.

\section{- Cooperation with national and international} technology transfer networks

Today's market of goods and services in Ukraine is not in a good situation. "Generators" of innovative products and services (universities, institutes, research institutions, inventors-individuals) cannot convey information about innovations to potential consumers sufficient due to the lack of specialized, reliable sources of information. On the other hand, companies and organizations that intend to produce innovative products and provide new services cannot fully get information about their respective industries' latest developments. Thus, the National Technology Transfer Network is designed for technology transfer and know-how between science and industry.

In late 2014 cooperation with the automated system of forming the integrated inter-state information, resources were started.

In July 2015, in university, an office of National Technology Transfer Network (NTTN), established by the European Network "relay centers" methodology, was created.

Cooperation with national technology transfer networks is the first stage of output CSTEI to the international transfer level. Effective international scientific grant activity is one of the keys to success in international technology transfer.

\section{- International scientific grant activities}

One of the priority directions of the development of the scientific potential of Ukraine is its integration into the European and world research space.

EU programs provide an excellent opportunity, in particular, research funding tool HORIZON 2020 [15].

The program aims to develop the economy based on the linkages between research and innovation and the "transfer of scientific ideas from the laboratory to market". Among the priority research areas is improving the competitiveness of production.
The program's already mentioned principle "transfer of ideas from the lab to the market" will positively impact science, industry and the economy. There will be opportunities to develop high-tech industries.

One of these activities in HORIZON 2020 is to finance small and medium enterprises SMEs - SMEs instrument.

SMEs are the leading provider of workplaces and innovations, and they paid particular attention to HORIZON 2020. SMEs can work together in a consortium and with support by special tools, creating small and highly innovative companies.

SME financing tool is a new approach to support their innovation activities.

The tool aims to support projects that create a new business (product, process, service, marketing), which leads to radical changes. It promotes companies into new markets, promotes their development and ensures a high return on investment. SME financing tool covers all types of innovative SMEs in all sectors.

Support of these activities will be combined with the R\&D development focus. Primary support will be provided to providing innovations to the market, including the public sector. It will allow using the potential of research infrastructures effectively.

«HORIZON 2020 is a tool of research funding [16] - information service of CSTEI, which allows finding partners from SMEs ready for joint research and implementation of technologies. In particular, this service provides access to information about university research directions, description of primary investigations and technological offers of SSU scientists, mechanisms of writing successful funding applications, and the list of information platforms for advertising scientific research.

\section{- The regional aspect of technology transfer}

In current conditions, a high level of development of fundamental and applied researches in Ukraine requires equivalent transfer mechanisms and implementation of research results into the real economy is very important. It is necessary to form structures connecting research, innovation and market innovation in science and technology. In current conditions, they contribute to integrating education, science, industry, government, and consumers for the interests of regions and countries' socio-economic development.

Along with high levels of protection documents for industrial property in universities, it should be noted that the transfer of intellectual property according to license agreements is singular. Innovative university activity in current conditions is determined by ability in a competitive environment and lack of material resources to create, protect and implement intellectual 
property. University policy should create favorable conditions for the emergence of highly competitive intellectual property with high market value.

Today innovative practices in universities are often imitating. The necessity usually causes imitation to correspond to high ratings, increasingly determining universities' future development and resource provision. In this regard, it is essential to define the methods of innovation development.

In our opinion, the university's most innovative organic needs will meet the creation of a system implementing intellectual assets of university scientists - technology transfer.

Universities need to step up innovation and marketing activities, allowing more effective use of $R \& D$ results in the production, increasing economic agreements, and involving scientists both in business and activities oriented on innovative infrastructure formation. Moreover, it needs more actively use the potential of innovative structures, university centers of marketing and technology transfer centers.

This aspect is discussed in the article on the example of CSTEI.

The effectiveness of CSTEI (CSTEI has not to profit as the primary purpose) is the number of requests and outstanding technological proposals, continuously updated sites, participation in scientific and technical exhibitions, the formation of packages of proposals for domestic and foreign companies, searching for business partners.

For the implementation of these tasks, we propose creating a regional technology transfer network. Target segments of the network are regional research organizations, public intuitions, businesses and entities of other regions (states) interested in technologies. This strategy assumes the maximum use of internet marketing (international communication, access for a technological proposals database) and information activities organization.

In addition to solving the fundamental problem, promoting technological cooperation among the organizations of scientific and educational sectors, companies, and enterprises, will move to implementing innovative development policy and creating innovative capacity dissemination opportunities.
For searching partners and promoting technology information in the network, we propose to use such information support tools, such as:

- United base of technological demands and proposals;

- Technology audit - check of offers/requests for readiness to transfer;

- Web-site network - a resource that provided the technological base of offers and requests;

- Periodic newsletters information about the network and new profiles of participants;

- Networking with network members and partners.

\section{Conclusion}

In current conditions, a high level of development of fundamental and applied researches requires equivalent transfer mechanisms and implementation of research results into the real economy is very important for education and research quality. Authors have considered the main models of technology transfer in Europe, the USA, Japan, China and the Ukrainian national legislative base in the technology transfer sphere. The main reasons for successful (at a systematic level) mechanisms of the technologies transfer were determined. Leading tendencies of technology transfer development in leading countries are presented. The necessity of creating technology transfer centers at universities as a place of the state intellectual potential concentration is substantiated. The authors proposed a list of ways and practical approaches for increasing technology transfer efficiency based on the complex approach to promote scientific research results on a networking basis. The issues of the regional aspect of the development of technology transfer networks are highlighted.

\section{Acknowledgments}

Ministry of Education and Science of Ukraine publicly funded the publication for developing of research projects "Innovation component of security of sustainable development of old industrial regions of Ukraine: strategic directions of institutional support and technology transfer in innovation landscapes» (№ 0121U100567, 2021-2023) and «Small-scale energy-saving modules with the use of multifunctional devices with intensive hydrodynamics for the production, modification and encapsulation of granules» (№ 0119U100834, 2019-2021). 


\section{References}

[1]. Vitaliy, O. (2015). Preconditions analysis of using of technological package concept for development strategy of space metallurgy. Metallurgical and Mining Industry, 7(8), 508-511.

[2]. Kwilinski, A., Dzwigol, H., \& Dementyev, V. (2020). Model of entrepreneurship financial activity of the transnational company based on intellectual technology. International Journal of Entrepreneurship, 24, 1-5.

[3]. Binda, J. B., Prokopenko, M., Ramskyi, A., Shuplat, O., Halan, L., \& Mykhaylenko, D. (2020). Assessment of Investment Attractiveness of Industrial Enterprises. International Journal of Management (IJM), 11(2), 27-35.

[4]. Gryshchenko, I. M. (2016). Factors enhancing the efficiency of education activity of higher education institutions in Ukraine. Aktual'ni Problemy Ekonomiky= Actual Problems in Economics, (177), 134.

[5]. Woerter, M. (2012). Technology proximity between firms and universities and technology transfer. The Journal of Technology Transfer, 37(6), 828-866.

[6]. DeCourcy, J. (2007). Research joint ventures and international competitiveness: evidence from the national cooperative research act. Economics of Innovation and New Technology, 16(1), 51-65.

[7]. Getsov, P., Mardirossian, G., Nedkov, R., Stoyanov, S., Bo, W., Prokopenko, O., \& Boyanov, P. (2017). Equipment for evaluation of the characteristics of electronic-optic converters. Доклади на Българската Академия на Науките, 70(11), 1575-1578.

[8]. Furmaniak, S., Gauden, P. A., Patrykiejew, A., Miśkiewicz, R., \& Kowalczyk, P. (2018). Carbon nanohorns as reaction nanochambers-a systematic Monte Carlo study. Scientific reports, 8(1), 1-9.
[9]. Pererva, P.G., Kosenko, A.V., \& Kosenko, O.P. (2009). Development of organizational structures of universities in technology transfer (commercialization of intellectual property). Mechanism of economic regulation, 4(2), 147-154.

[10]. Belinko, K., Paterson, M., \& Deschatelets, C. (2004). A Technology Transfer Decision Framework for Publicly Funded Research Organizations. Federal Partners in Technology Transfer, Canada.

[11]. Lamine, W., Mian, S., Fayolle, A., Wright, M., Klofsten, M., \& Etzkowitz, H. (2018). Technology business incubation mechanisms and sustainable regional development. The Journal of Technology Transfer, 43(5), 1121-1141.

[12]. Artyukhov, A., Obodiak, V., Boiko, P., \& Rossi, P. (2017). Computer modeling of hydrodynamic and heat-mass transfer processes in the vortex type granulation devices. In CEUR Workshop Proceedings (pp. 33-47).

[13]. Evstafyev, D.S., Molchanov, N.N., \& Sharahin, P.S. (2006). Marketing in the Information Society. Spb.

[14]. Luksha, O. (2006). Technology Commercialization Center - organizational development: how to create, manage, monitor and evaluate activities. Project Europe Aid "Science and Technology Commercialisation". EU.

[15]. Horizon 2020, (2020). European Commission Europa EU. Retrieved from: http://ec.europa.eu/programmes/horizon2020/ [accessed: 17. November 2020].

[16]. Horizon 2020, (2020). Sumy State University. Retrieved from: http://horizon2020.sumdu.edu.ua/ [accessed: 17. November 2020]. 